\title{
New Approaches for Studying Synaptic Development, Function, and Plasticity Using Drosophila as a Model System
}

\author{
C. Andrew Frank, ${ }^{1}$ Xinnan Wang, ${ }^{2}$ Catherine A. Collins, ${ }^{3}$ Avital A. Rodal, ${ }^{4}$ Quan Yuan, ${ }^{5}$ Patrik Verstreken, ${ }^{6}$ \\ and Dion K. Dickman ${ }^{7}$ \\ ${ }^{1}$ Department of Anatomy and Cell Biology, University of Iowa Carver College of Medicine, Iowa City, Iowa 52242, ${ }^{2}$ Stanford Institute for Neuro-innovation \\ and Translational Neurosciences and Department of Neurosurgery, Stanford University School of Medicine, Palo Alto, California 94305, ${ }^{3}$ Department of \\ Molecular Cellular and Developmental Biology, University of Michigan, Ann Arbor, Michigan 48109, ${ }^{4}$ Department of Biology, Brandeis University, \\ Waltham, Massachusetts 02453, ${ }^{5}$ National Institute of Neurological Disorders and Stroke, National Institute of Health, Bethesda, Maryland 20892, ${ }^{6}$ VIB, \\ Center for the Biology of Disease and KU Leuven, Department for Human Genetics, 3000 Leuven, Belgium, and Department of Biology, University of \\ Southern California, Los Angeles, California 90089
}

The fruit fly Drosophila melanogaster has been established as a premier experimental model system for neuroscience research. These organisms are genetically tractable, yet their nervous systems are sufficiently complex to study diverse processes that are conserved across metazoans, including neural cell fate determination and migration, axon guidance, synaptogenesis and function, behavioral neurogenetics, and responses to neuronal injury. For several decades, Drosophila neuroscientists have taken advantage of a vast toolkit of genetic and molecular techniques to reveal fundamental principles of neuroscience illuminating to all systems, including the first behavioral mutants from Seymour Benzer's pioneering work in the 1960s and 1970s, the cloning of the first potassium channel in the 1980s, and the identification of the core genes that orchestrate axon guidance and circadian rhythms in the 1990s. Over the past decade, new tools and innovations in genetic, imaging, and electrophysiological technologies have enabled the visualization, in vivo, of dynamic processes in synapses with unprecedented resolution. We will review some of the fresh insights into synaptic development, function, and plasticity that have recently emerged in Drosophila with an emphasis on the unique advantages of this model system.

\section{Introduction}

Drosophila melanogaster has been a prominent model organism in biological research for more than a century. During this time, fruit fly researchers have made groundbreaking discoveries in numerous fields, including neuroscience (Bier, 2005; Bellen et al., 2010). Beginning in the 1960s, Seymour Benzer pioneered the field of Drosophila neurogenetics, hypothesizing that complex behavioral traits could be mapped to unique genetic loci (Benzer, 1967; Greenspan, 2008). In an era before recombinant DNA technology, work initiated in the Benzer laboratory led to fundamental discoveries that reverberate today, including the identification and characterization of ion channel gene mutations and their

Received July 31, 2013; revised Aug. 25, 2013; accepted Aug. 27, 2013.

This work was supported by a National Institutes of Health Grant MH092351 and a New Scholar Award from the Ellison Medical Foundation to D.K.D.; National Institutes of Health Grant NS062738 and support from the University of lowa Carver Trust to C.A.F.; National Institutes of Health Grants NS60947 and NS082127, and a Basil O'Connor Scholar award from the March of Dimes to A.A.R.; a European Research Counsel Starting Grant, the Fonds voor Wetenschappelijk Onderzoek Vlaanderen, BELSPO interuniversitaire attractive pool, the research fund KU Leuven, the Instituut voor Wetenschap en Technologie Vlaanderen, the Fundação para a Ciência e a Tecnologia, and VIB to P.V.; National Institutes of Health Grant NS067066 and fellowships from the Bumpus, Sloan, Klingenstein, and Michael J. Fox Foundations to X.W.; National Institutes of Health Grant NS069844 and National Science Foundation Grant IOS-0842701 to C.A.C.; and the intramural research program of the National Institute of Neurological Disorders and Stroke to Q.Y.

The authors declare no competing financial interests.

Correspondence should be addressed to Dr. Dion K. Dickman, Department of Biology, University of Southern California, HNB 309, 3641 Watt Way, Los Angeles, CA 90089. E-mail: dickman@usc.edu.

DOI:10.1523/JNEUROSCI.3261-13.2013

Copyright $\odot 2013$ the authors $\quad 0270-6474 / 13 / 3317560-09 \$ 15.00 / 0$ regulators (Jan et al., 1977; Wu and Ganetzky, 1980; Wu et al., 1983), the elucidation of the circadian clock (Konopka and Benzer, 1971), and the identification of genes that influence the complex process of learning and memory (Dudai et al., 1976).

The 1980s and1990s brought forth an impressive expansion of the Drosophila genetic toolkit, including transgenic animals ( $\mathrm{Ru}-$ bin and Spradling, 1982), transposon-mediated mutagenesis (Bellen et al., 1989; Bier et al., 1989; Wilson et al., 1989), mosaic analysis (Golic and Lindquist, 1989; Golic, 1991), and tissuespecific control of gene expression (Fischer et al., 1988; Brand and Perrimon, 1993; Greig and Akam, 1993; Kaiser, 1993). In the past decade, there have been advances that enable the labeling of genetically distinct neurons or lineages (Lee and Luo, 2001) and the targeting of any gene in the fly genome for mutation (Rong and Golic, 2000) or knockdown (Dietzl et al., 2007; Ni et al., 2008, 2009). In the realm of neuroscience, these advances have been combined with classical forward genetic screening approaches to usher in a wealth of new information in diverse fields, including synaptic transmission (Schwarz, 2006), axon guidance (Dickson and Zou, 2010; Evans and Bashaw, 2010), eye development (Thomas and Wassarman, 1999), and olfaction (Davis, 1996, 2005; Fiala, 2007).

Drosophila neuroscientists are uniquely positioned to address fundamental questions in synapse biology. At the primary amino acid level, synaptic proteins in Drosophila are, on average, $>70 \%$ similar to their mammalian counterparts; and with few exceptions, every mammalian protein has a fruit fly ortholog (Littleton 

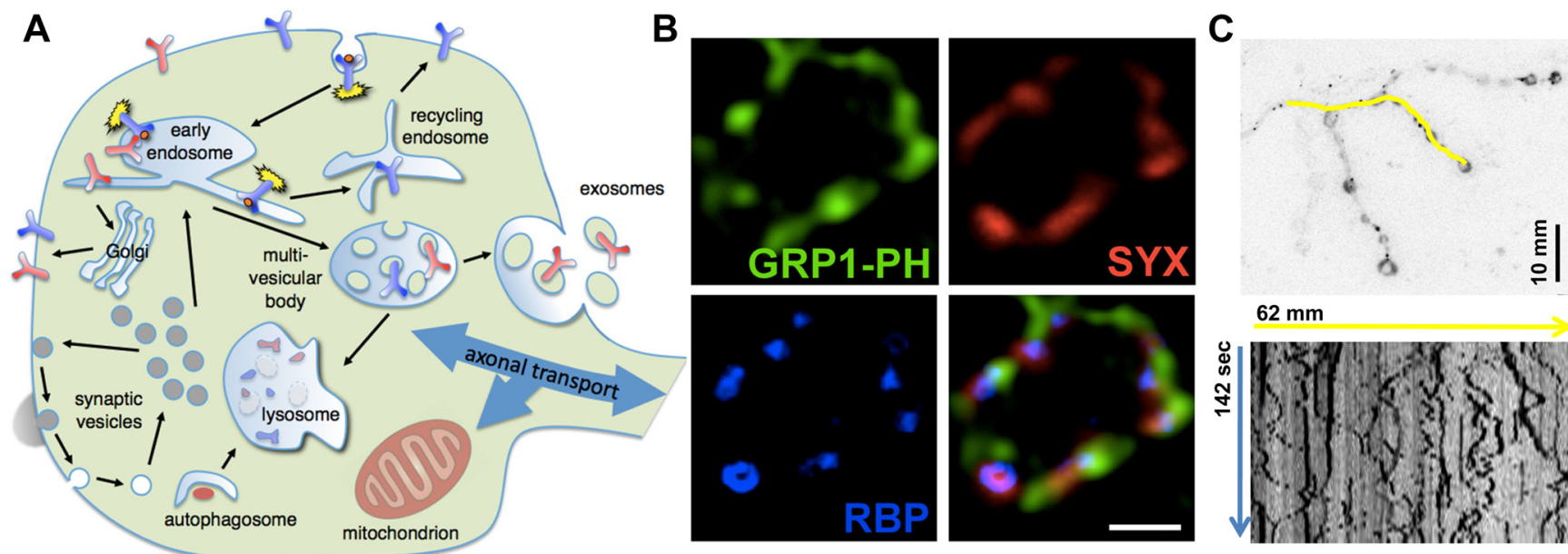

$62 \mathrm{~mm}$

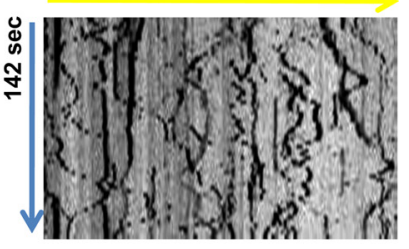

Figure 1. Visualization of membrane trafficking dynamics in Drosophila. $A$, Schematic of intersecting trafficking pathways in synaptic boutons at the Drosophila NMJ. $B$, Super resolution imaging (photobleaching microscopy with nonlinear processing) (Munck et al., 2012) of a larval synaptic bouton expressing N- and (-Split Venus-GRP1-PH (green), a marker for PI(3,4,5) $\mathrm{P}_{3}$, and immunolabeled with anti-Syntaxin $1 \mathrm{~A}$ (red) and anti-Rim Binding Protein (RBP, blue) (Khuong et al., 2013). The images indicate that $\mathrm{PI}(3,4,5) \mathrm{P}_{3}$ and Syntaxin $1 \mathrm{~A}$ cluster preferentially at active zones that are marked by RBP. Scale bar, $500 \mathrm{~nm}$. Image courtesy of Thang Manh Khuong (KU Leuven, Leuven, Belgium). C, Live imaging reveals trafficking of the BMP receptor Tkv-mCherry in synaptic boutons (top), and dynamic movement along axon terminals (indicated in yellow as a kymograph; bottom).

and Ganetzky, 2000; Littleton, 2000; Lloyd et al., 2000). Given an extensive array of powerful approaches, Drosophila neuroscientists are in pole-position to elucidate the functions of synaptic proteins and the many processes in which they participate.

\section{Advances in synaptic trafficking}

Motor neurons in third-instar Drosophila larvae are exceptional models to study organelle trafficking in an organismal context (Fig. 1A), given the unique and powerful combination of modern molecular genetic, electrophysiological, and imaging technologies available (Venken et al., 2011). Motor neuron axons and terminals are found near the surface of the muscle, where they are directly accessible for imaging and electrophysiology in filleted preparations. In addition, neurons and subsynaptic structures can be easily and repeatedly imaged through the cuticle over many days of development in intact larvae (Füger et al., 2007; Schmid et al., 2008; Ghannad-Rezaie et al., 2012). These assays in fly axons and synapses have enabled some of the first in vivo measurements of synaptic trafficking rates ever obtained in a model organism and have advantages over cultured systems because they reveal neuronal processes within an intact developmental context. In contrast, in vivo studies of comparable resolution and sophistication are difficult in mammalian models because of challenges in accessing structures deep in tissue, the long generation times, and the often limited reagents necessary for complex genetic experiments. Furthermore, the impact of membrane trafficking processes in fly neurons can be effectively determined within the context of higher-order processes, such as synapse formation, transmission, motor function, and neurodegeneration, making Drosophila a powerful system to understand molecular, cellular, synaptic, circuit, and behavioral functions. Here, we will discuss recent developments, using the larval neuromuscular junction (NMJ), that have led to novel insights into the trafficking of synaptic vesicles, endosomes, and mitochondria.

Synaptic boutons at the Drosophila larval NMJ are quite large (2-5 $\mu \mathrm{m}$ diameter) and are thus easily amenable to light microscopy. Recent advances in super resolution imaging have enabled the visualization of synaptic structures beyond the diffraction limit, yielding molecular insight into the organization, structure, and function of synaptic vesicle release sites (Owald et al., 2010, 2012; Liu et al., 2011; Miśkiewicz et al., 2011). We have used super resolution imaging and a novel lipid binding reagent we developed to reveal new insights into the active zone at the presynaptic membrane. Using a split-Venus fluorophore fused to the general receptor for phosphoinositides 1 pleckstrin homology domain (GRP1-PH), we demonstrated that a very low-abundance lipid, $\mathrm{PI}(3,4,5) \mathrm{P}_{3}$, localizes to synaptic vesicle release sites and is necessary and sufficient to cluster Syntaxin $1 \mathrm{~A}$, a protein required for vesicle fusion (Khuong et al., 2013) (Fig. 1B). These and numerous other studies in Drosophila have established a foundation to start building a molecular model for how proteins and lipids interact to regulate neurotransmitter release in healthy and diseased neurons (Lauwers and Verstreken, 2013).

The ability to image synaptic processes at the larval NMJ has also enabled us to delineate the function of endosomes in the synaptic vesicle cycle. Although compartments that harbor endosomal markers are present at synapses (Wucherpfennig et al., 2003), their role in the synaptic vesicle cycle has remained controversial (Zenisek et al., 2000; Opazo et al., 2010). Our synaptic transmission screens isolated a novel and evolutionary conserved GTPase-activating protein that we named Skywalker (Sky). Using live imaging of synaptic vesicles and time course electron microscopy and tomography, we found that most synaptic vesicles are forced to traffic via an endosomal compartment in sky mutants (Uytterhoeven et al., 2011). To our surprise, synaptic transmission in sky mutants is significantly increased, and the size of the readily releasable synaptic vesicle pool is markedly larger. We reasoned that dysfunctional proteins may be sorted locally in synaptic terminals for degradation through endosomal compartments, and this process may be facilitated in sky mutants. These synapses, in turn, may have a higher ratio of synaptic vesicles with "more functional" proteins, leading to increased neurotransmitter release. To test this hypothesis, we constructed an artificial synaptic vesicle protein as a substrate for degradation. This protein was indeed very efficiently degraded in sky mutant animals compared with wild-type (Henne et al., 2011). Hence, genetic and dynamic imaging approaches revealed that endosomes may serve as sorting stations for the local degradation of dysfunctional synaptic vesicle proteins. Given that the human homolog of sky, 
TBC1D24, has been found mutated in epileptic patients and has recently also been linked to neuronal survival (Poduri and Lowenstein, 2011), endosomal sorting of synaptic vesicles may also be medically relevant.

The larval NMJ is also an outstanding system to study how neurons integrate intracellular membrane trafficking pathways to transduce growth signals and how these events may be altered in disease. During larval development, synaptic growth is driven through diverse mechanisms involving neuronal activity, glial influences, and target-derived signals (Packard et al., 2002; Marqués and Zhang, 2006; Fuentes-Medel et al., 2012) and depends on trafficking of growth factors and presynaptic signaling receptor complexes (Dickman et al., 2006; O'Connor-Giles et al., 2008; Rodal et al., 2008, 2011). Indeed, pioneering forward genetic screens in Drosophila based on visual observation of intact larval synapses have discovered novel and conserved regulators of synaptic growth, including highwire/rpm1/Pam/Phrl and bone morphogenic proteins (BMPs) (Wan et al., 2000; Aberle et al., 2002; Marqués et al., 2002). Work in Drosophila has revealed that endosomal cargoes take remarkably varied yet intersecting routes within presynaptic terminals (Fig. 1A), trafficking between diverse synaptic compartments (Wang et al., 2007; Rodal et al., 2008, 2011; Korkut et al., 2009; Kim et al., 2010; Koles et al., 2012), yet synaptic endosomal function remains poorly understood.

We recently developed live-imaging assays to directly visualize receptor signaling and endosomal dynamics simultaneously (Fig. $1 C$ ). These compartmental movements occur at very high speeds (up to several micrometers per second) and were impossible to measure until recent advances in spinning disk confocal technology and genetically encoded fluorophores. These studies have revealed that transient interactions between the membraneremodeling proteins Nervous Wreck (Nwk) and Sorting Nexin 16 on presynaptic early and recycling endosomes correlate with down-regulation of receptor signaling activity (Rodal et al., 2011). This led us to investigate the membrane-deforming activity of Nwk, a member of the F-BAR protein family (Becalska et al., 2013). We found that Nwk exhibits an unconventional higherorder zigzag assembly of the F-BAR domain, leading to novel deforming activities: membrane ridging, scalloping, and negative curvature. This suggests that cargo transfer between these synaptic endosomes occurs by a unique mechanism distinct from conventional tubulation-mediated sorting (Campelo and Malhotra, 2012). In addition, we have recently monitored the trajectory of two synaptic growth-promoting transmembrane cargoes, the BMP receptor Thickveins (Tkv) and the amyloid precursor protein (A. Becalska, Z. Feiger, M. Zunitch, and A. Rodal, unpublished data). Within the same nerve terminal, these two cargoes traffic via distinct endosomal pathways and are profoundly affected in neurodegenerative disease models. Tkv trafficking and signaling are perturbed in a fly model of amyotrophic lateral sclerosis, whereas amyloid precursor protein traffic is altered upon manipulation of the endosomal retromer complex, which is linked to Alzheimer's disease (Muhammad et al., 2008; Small, 2008; Wen et al., 2011). These observations suggest that the compromised function of different endocytic pathways can lead to distinct disease manifestations. One particularly interesting area of future research will be to investigate how these endosomal pathways integrate with those regulating the synaptic vesicle cycle.

Mitochondrial transport and distribution in neurons are critical for synaptic integrity and function, given their vital roles in ATP synthesis, $\mathrm{Ca}^{2+}$ buffering, and apoptosis. Forward genetic screens in Drosophila have identified two mitochondrial adaptors, Milton and Miro, which are necessary for anterograde movement of mitochondria in axons (Stowers et al., 2002; Guo et al., 2005; Glater et al., 2006). Imbalances in mitochondrial trafficking have been linked to human neurological disease and modeled in flies (Shidara and Hollenbeck, 2010; Wang et al., 2011; Iijima-Ando et al., 2012). For example, two hereditary forms of Parkinson's disease (PD) arise from mutations in the Ser/Thr kinase PINK1 and the E3 ubiquitin ligase Parkin (Kitada et al., 1998; Valente et al., 2004). Genetic and live-imaging studies in Drosophila were the first to establish that PINK1 functions in part upstream of Parkin to control mitochondrial motility and morphology (Clark et al., 2006; Park et al., 2006; Yang et al., 2006; Exner et al., 2007; Poole et al., 2008; Wang et al., 2011; Liu et al., 2012). Mammalian work has also established this pathway in damaged mitochondrial clearance via mitophagy (Narendra et al., 2008, 2012; Geisler et al., 2010; Haddad et al., 2013). Recent work using large-scale genomic or proteomic approaches in Drosophila has further demonstrated the importance of PINK1 in maintaining the mitochondrial electron transport chain and protein turnover in vivo (Morais et al., 2009; Vilain et al., 2012; Vos et al., 2012; Esposito et al., 2013; Vincow et al., 2013). Together, these approaches in Drosophila have revealed mechanistic insights into the regulatory dynamics of mitochondria and their significance in the etiology of PD.

Our studies and those of others have also revealed that mutations in several of the PD-related genes, including pink1, parkin, and $L R R K 2$, lead to defects in synaptic vesicle trafficking in both flies and rodents (Gautier et al., 2008; Morais et al., 2009; Lee et al., 2010; Piccoli et al., 2011; Poduri and Lowenstein, 2011; Matta et al., 2012; Haddad et al., 2013). Although loss of pink1 and parkin may affect synaptic transmission because of mitochondrial defects (Verstreken et al., 2005), we discovered that fly LRRK and mammalian LRRK2 directly phosphorylate EndophilinA (Matta et al., 2012), a critical gene for synaptic vesicle endocytosis (Verstreken et al., 2002; Dickman et al., 2005; Milosevic et al., 2011). Misregulation in LRRK-dependent EndophilinA phosphorylation causes defects in membrane association and synaptic vesicle endocytosis; and interestingly, Parkin has been shown to ubiquitinate EndophilinA (Trempe et al., 2009). These studies not only reveal a novel LRRK2 substrate but implicate dysfunction in synaptic vesicle trafficking in the etiology of PD. Thus, powerful genetic and live imaging approaches developed in Drosophila have provided a unique tool to uncover fundamental mechanisms of synaptic organelle traffic in health and disease.

\section{Advances in homeostatic synaptic plasticity}

Recent studies have demonstrated that the nervous system is endowed with potent and adaptive mechanisms that respond to perturbations that disrupt electrical activity and restore normal functionality, termed homeostatic plasticity. Homeostatic regulation has been identified in nervous systems of both vertebrates and invertebrates, indicating that this is an evolutionarily conserved form of neural regulation (Davis, 2006; Nelson and Turrigiano, 2008; Turrigiano, 2008; Vitureira et al., 2012). Synapses, as fundamental units of nervous system function, are key substrates to achieve and maintain the homeostatic control of neural function. However, the genes and molecular mechanisms that orchestrate these complex and fundamental signaling systems are virtually unknown. Although vertebrate studies have demonstrated robust homeostatic signaling and found a few intriguing molecules involved, including retinoic acid, BDNF, TNF- $\alpha$, and 

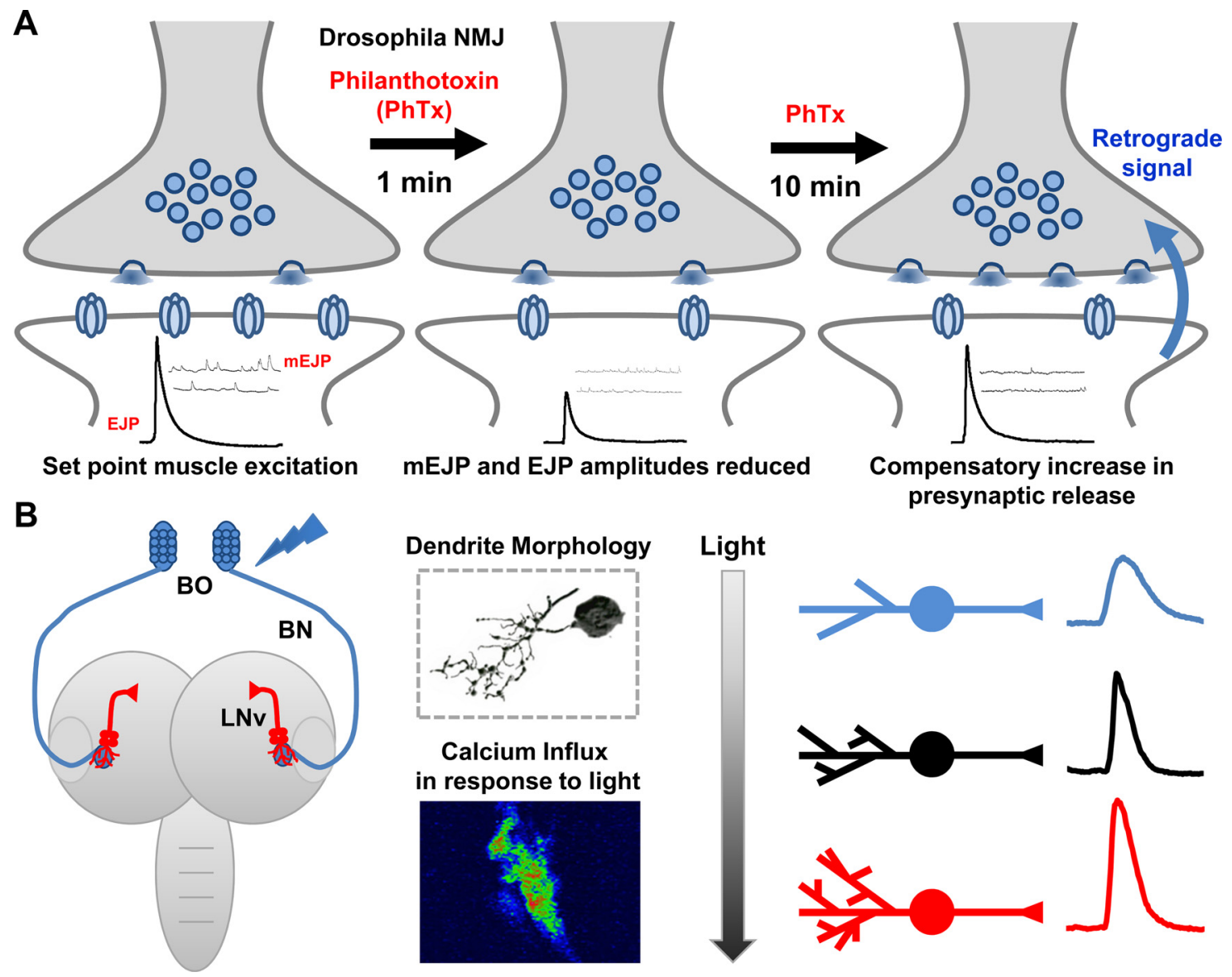

Figure 2. Drosophila models of homeostatic synaptic plasticity. A, Schematic of homeostatic compensation after application of the postsynaptic glutamate receptor antagonist philanthotoxin (PhTx) to the larval NMJ. Application of PhTx initially causes an $\sim 50 \%$ decrease in miniature excitatory junction potential (mEJP) amplitude and a parallel $\sim 50 \%$ decrease in evoked excitatory junction potential (EJP) amplitude. After 10 min incubation in PhTx, mEJP amplitudes remain depressed whereas EJP amplitudes increase to baseline values resulting from a homeostatic enhancement of presynaptic neurotransmitter release (quantal content). $\boldsymbol{B}$, Schematic of the larval visual circuit; the light sensing BO sends an axon projection (BN) into the larval brain where it synapses with the LNv (left). LNvs exhibit activity-dependent structural and functional plasticity, demonstrated by $3 \mathrm{D}$ tracing and calcium imaging (middle). Light exposure bidirectionally alters dendrite length and synaptic activity (right).

Arc (Pozo and Goda, 2010), progress in gene discovery in these systems is limited. Recently, the larval NMJ and visual system in Drosophila have emerged as powerful models for studying homeostatic synaptic plasticity, enabling the elucidation of these processes in a system amenable to forward genetic approaches.

The landmark publication demonstrating homeostatic control of synaptic function was made by Gina Turrigiano and colleagues $\sim 15$ years ago (Turrigiano et al., 1998). Around this time, genetic mutants and manipulations to postsynaptic glutamate receptors at the Drosophila NMJ revealed the surprising existence of a retrograde, homeostatic synaptic signaling mechanism (Petersen et al., 1997; Davis et al., 1998). Here, an increase in presynaptic release was observed that precisely compensated for reduced postsynaptic receptor function, adaptively restoring normal postsynaptic activity. Diverse perturbations have been shown to induce this phenomenon, including altered synaptic inputs (Davis and Goodman, 1998), reduced excitability of the postsynaptic muscle (Paradis et al., 2001), and alterations in postsynaptic glutamate receptor classes, expression levels, or sensitivity (for review, see Frank, 2013). Further, acute pharmacological blockade of postsynaptic receptors demonstrated that this form of homeostatic compensation was surprisingly rapid, occurring in 10 min (Frank et al., 2006). Finally, the homeostatic control of presynaptic function is bidirectional. Some genetic perturbations induce increased presynaptic vesicle size. This can result in increased quantal size and a concomitant homeostatic reduction in presynaptic release (quantal content), restoring normal postsynaptic responsiveness (Daniels et al., 2004).

Using an acute pharmacological assay (detailed in Fig. 2A), we undertook an electrophysiology-based forward genetic screen of $>350$ mutants for potential roles in homeostatic synaptic plasticity, isolating seven novel mutations. This screen identified the Drosophila homolog of the vertebrate gene dysbindin to be required for adaptive synaptic plasticity (Dickman and Davis, 2009). Interestingly, the human homolog of this gene has been found to be a susceptibility gene for schizophrenia (Ross et al., 2006), raising the intriguing possibility that defects in homeostatic plasticity may contribute to the etiology of complex neuropsychiatric diseases. Dysbindin is part of large protein complex called the Biogenesis of Lysosome-related Organelles Complex (Ghiani and Dell'Angelica, 2011), and we recently showed that another member of this complex, the synaptic vesicle protein Snapin, is also required for synaptic homeostasis (Dickman et al., 2012). Thus, this forward screening approach identified an unanticipated protein complex in presynaptic homeostatic plasticity and revealed intriguing links with neuropsychiatric disease. 
This screen also led to the discovery of unanticipated roles for potassium channels in homeostatic regulation (Bergquist et al., 2010), as well as a novel calcium-binding protein and neurotransmitter receptor (D. K. Dickman et al., unpublished data). In addition, subsequent screens and other studies have found diverse genes and processes to be involved in synaptic homeostasis, including Rab3, Ephexin, calcium signaling, synaptic vesicle pool sizes, axonal transport, and postsynaptic translation (Frank et al., 2009; Tsurudome et al., 2010; Müller et al., 2011, 2012; Penney et al., 2012; Frank, 2013). A challenge for the future will be to delineate how the homeostat integrates these complex and diverse signaling pathways to precisely modulate synaptic strength. Together with dynamic imaging methods that are being developed (Müller and Davis, 2012), the Drosophila NMJ will continue to be a powerful system to identify the genes and elucidate the mechanisms that orchestrate the homeostatic control of synaptic function.

In addition to the Drosophila NMJ, we recently identified robust homeostatic modulation of both synaptic structure and function in the fly larval visual system (Yuan et al., 2011). Visual experience during larval development in the CNS drastically modifies the dendritic arbor of ventral lateral neurons (LNvs), a group of second-order cells postsynaptic to the primary larval photoreceptor, Bolwig's organ (BO) (Schmucker et al., 1992; Malpel et al., 2002). Light stimulation induces structural changes in LNv dendritic complexity and size as well as physiological responses inverse to the amount of light stimulation (Fig. 2B). Indeed, increased light exposure reduces dendritic arbors and synaptic responses in LNvs, whereas reduced light exposure leads to increased dendritic size and responsiveness. These compensatory changes are similar in principle to the homeostatic adjustment of synaptic strength observed at the NMJ. Because LNvs are critical components in the neural circuits controlling circadian rhythms and larval light avoidance behaviors (Helfrich-Forster, 1998; Mazzoni et al., 2005), this modulation of dendritic morphology and physiology may serve important functions in the behavioral adaptation to changing environmental conditions.

The bidirectional homeostatic plasticity observed in the Drosophila CNS provides an opportunity to use genetic screens to identify genes involved in these processes. We have recently performed genome-wide RNAi and loss-of-function mutant screens, identifying a number of interesting candidates, including novel cell adhesion molecules, to be required for homeostatic structural plasticity in dendrites (Yuan et al., 2011). This system has also provided insights into local inhibitory inputs in regulating experience-dependent plasticity, which mammalian work has found to be the driving force for critical period plasticity in the primary visual cortex (Hensch, 2004; Espinosa and Stryker, 2012). In the fly larval visual system, anatomical evidence has suggested that both excitatory and inhibitory inputs interact with the BO-LNv synapses (Hamasaka et al., 2005, 2007). By manipulating activity of inhibitory neurons and receptor expression on LNvs, we observed strong influences on LNv dendritic plasticity (Q. Yuan et al., unpublished data). We are currently searching for developmental and environmental cues that modulate wiring plasticity in the fly visual circuit. New genetic screens and calcium imaging technologies will continue to provide mechanistic insights into the homeostatic control of structural and functional synaptic plasticity.

\section{Advances in synaptic degeneration and repair}

A dramatic form of synaptic plasticity is the loss and clearance of defective or damaged synapses and the structural remodeling necessary to generate new connections. A number of assays have recently been developed in Drosophila to study the degeneration and regeneration of axons, dendrites, and synapses (Leyssen et al., 2005; Hoopfer et al., 2006; MacDonald et al., 2006; Massaro et al., 2009; Stone et al., 2010; Xiong et al., 2010, 2012; Tao and Rolls, 2011; Fang and Bonini, 2012; Song et al., 2012; Xiong and Collins, 2012). Hence, the power of Drosophila genetics can now be brought to bear upon these topics, which are of great therapeutic interest.

Not surprisingly, discoveries in flies have been shown to hold true for vertebrates as well. A striking example of this is the essential role for a conserved axonal Dileucine Zipper kinase named Wallenda (Wnd) in Drosophila in the regeneration of injured axons in multiple model organisms (Hammarlund et al., 2009; Yan et al., 2009; Xiong et al., 2010; Shin et al., 2012). Wnd becomes acutely activated by axonal injury and mediates a transcriptional response to promote new axonal growth (Xiong et al., 2010). Wnd was originally identified as a target of the Highwire (Hiw) E3 ubiquitin ligase during synaptic development in a forward genetic suppressor screen. Excessive levels (and activity) of Wnd protein lead to synaptic overgrowth in hiw mutants (Wan et al., 2000; Collins et al., 2006). We have recently identified a new role for Wnd in organizing microtubules during synaptic development at the NMJ (Klinedinst et al., 2013), demonstrating that Wnd has dual functions in both synaptic development and axonal regeneration. We hypothesize that the turnover of Wnd by Hiw may serve as a sensor for the state of the synapse, promoting new synaptic growth during development and after injury.

The mechanisms driving axonal degeneration remain poorly understood. A prevailing hypothesis has been that axons degenerate through an active "self destruction" pathway, analogous to, but molecularly distinct from, apoptosis (Wang et al., 2012). This hypothesis was the basis of a recent brute-force genetic screen in Drosophila, which discovered a novel gene, Sarm, to be essential for axonal degeneration (Osterloh et al., 2012). We have found that Hiw also plays a similarly critical role in axonal degeneration by regulating the levels of the NAD biosynthetic enzyme NMNAT (Xiong et al., 2012). Subsequent work has shown that homologs of both Hiw and Sarm function in axonal degeneration in mice (Osterloh et al., 2012; Babetto et al., 2013). Future studies using genetically encoded reporters for cellular events, including mitochondrial movement, calcium imaging, and cytoskeletal dynamics, will be used to study both regeneration and degeneration within the context of native circuits in a living animal. Therefore, Drosophila is certain to be a leading system to enable discoveries of additional players and their mechanistic relationships in the mysterious process of neuronal degeneration.

In conclusion, we have highlighted several examples of the current approaches being used in Drosophila, which have merged genetic, imaging, and electrophysiological technologies to reveal new insights into synaptic development, function, and plasticity. With these powerful tools and a new generation of researchers, synaptic studies in Drosophila will continue to pioneer new discoveries in diverse areas of neuroscience research.

\section{References}

Aberle H, Haghighi AP, Fetter RD, McCabe BD, Magalhães TR, Goodman CS (2002) wishful thinking encodes a BMP type II receptor that regulates synaptic growth in Drosophila. Neuron 33:545-558. CrossRef Medline

Babetto E, Beirowski B, Russler EV, Milbrandt J, DiAntonio A (2013) The phr1 ubiquitin ligase promotes injury-induced axon self-destruction. Cell Rep 3:1422-1429. CrossRef Medline

Becalska AN, Kelley CF, Berciu C, Stanishneva-Konovalova TB, Fu X, Wang S, Sokolova OS, Nicastro D, Rodal AA (2013) Formation of membrane 
ridges and scallops by the F-BAR protein Nervous Wreck. Mol Biol Cell 24:2406-2418. CrossRef Medline

Bellen HJ, O'Kane CJ, Wilson C, Grossniklaus U, Pearson RK, Gehring WJ (1989) P-element-mediated enhancer detection: a versatile method to study development in Drosophila. Genes Dev 3:1288-1300. CrossRef Medline

Bellen HJ, Tong C, Tsuda H (2010) 100 years of Drosophila research and its impact on vertebrate neuroscience: a history lesson for the future. Nat Rev Neurosci 11:514-522. CrossRef Medline

Benzer S (1967) Behavioral mutants of Drosophila isolated by countercurrent distribution. Proc Natl Acad Sci U S A 58:1112-1119. CrossRef Medline

Bergquist S, Dickman DK, Davis GW (2010) A hierarchy of cell intrinsic and target-derived homeostatic signaling. Neuron 66:220-234. CrossRef Medline

Bier E (2005) Drosophila, the golden bug, emerges as a tool for human genetics. Nat Rev Genet 6:9-23. CrossRef Medline

Bier E, Vaessin H, Shepherd S, Lee K, McCall K, Barbel S, Ackerman L, Carretto R, Uemura T, Grell E (1989) Searching for pattern and mutation in the Drosophila genome with a P-lacZ vector. Genes Dev 3:12731287. CrossRef Medline

Brand AH, Perrimon N (1993) Targeted gene expression as a means of altering cell fates and generating dominant phenotypes. Development 118: 401-415. Medline

Campelo F, Malhotra V (2012) Membrane fission: the biogenesis of transport carriers. Annu Rev Biochem 81:407-427. CrossRef Medline

Clark IE, Dodson MW, Jiang C, Cao JH, Huh JR, Seol JH, Yoo SJ, Hay BA, Guo M (2006) Drosophila pink1 is required for mitochondrial function and interacts genetically with parkin. Nature 441:1162-1166. CrossRef Medline

Collins CA, Wairkar YP, Johnson SL, DiAntonio A (2006) Highwire restrains synaptic growth by attenuating a MAP kinase signal. Neuron 51: 57-69. CrossRef Medline

Daniels RW, Collins CA, Gelfand MV, Dant J, Brooks ES, Krantz DE, DiAntonio A (2004) Increased expression of the Drosophila vesicular glutamate transporter leads to excess glutamate release and a compensatory decrease in quantal content. J Neurosci 24:10466-10474. CrossRef Medline

Davis GW (2006) Homeostatic control of neural activity: from phenomenology to molecular design. Annu Rev Neurosci 29:307-323. CrossRef Medline

Davis GW, Goodman CS (1998) Synapse-specific control of synaptic efficacy at the terminals of a single neuron. Nature 392:82-86. CrossRef Medline

Davis GW, DiAntonio A, Petersen SA, Goodman CS (1998) Postsynaptic PKA controls quantal size and reveals a retrograde signal that regulates presynaptic transmitter release in Drosophila. Neuron 20:305-315. CrossRef Medline

Davis RL (1996) Physiology and biochemistry of Drosophila learning mutants. Physiol Rev 76:299-317. Medline

Davis RL (2005) Olfactory memory formation in Drosophila: from molecular to systems neuroscience. Annu Rev Neurosci 28:275-302. CrossRef Medline

Dickman DK, Davis GW (2009) The schizophrenia susceptibility gene dysbindin controls synaptic homeostasis. Science 326:1127-1130. CrossRef Medline

Dickman DK, Horne JA, Meinertzhagen IA, Schwarz TL (2005) A slowed classical pathway rather than kiss-and-run mediates endocytosis at synapses lacking synaptojanin and endophilin. Cell 123:521-533. CrossRef Medline

Dickman DK, Lu Z, Meinertzhagen IA, Schwarz TL (2006) Altered synaptic development and active zone spacing in endocytosis mutants. Curr Biol 16:591-598. CrossRef Medline

Dickman DK, Tong A, Davis GW (2012) Snapin is critical for presynaptic homeostatic plasticity. J Neurosci 32:8716-8724. CrossRef Medline

Dickson BJ, Zou Y (2010) Navigating intermediate targets: the nervous system midline. Cold Spring Harbor Perspect Biol 2:a002055. CrossRef Medline

Dietzl G, Chen D, Schnorrer F, Su KC, Barinova Y, Fellner M, Gasser B, Kinsey K, Oppel S, Scheiblauer S, Couto A, Marra V, Keleman K, Dickson BJ (2007) A genome-wide transgenic RNAi library for conditional gene inactivation in Drosophila. Nature 448:151-156. CrossRef Medline
Dudai Y, Jan YN, Byers D, Quinn WG, Benzer S (1976) dunce, a mutant of Drosophila deficient in learning. Proc Natl Acad Sci U S A 73:1684-1688. CrossRef Medline

Espinosa JS, Stryker MP (2012) Development and plasticity of the primary visual cortex. Neuron 75:230-249. CrossRef Medline

Esposito G, Vos M, Vilain S, Swerts J, De Sousa Valadas J, Van Meensel S, Schaap O, Verstreken P (2013) Aconitase causes iron toxicity in Drosophila pink1 mutants. PLoS Genet 9:e1003478. CrossRef Medline

Evans TA, Bashaw GJ (2010) Axon guidance at the midline: of mice and flies. Curr Opin Neurobiol 20:79-85. CrossRef Medline

Exner N, Treske B, Paquet D, Holmström K, Schiesling C, Gispert S, CarballoCarbajal I, Berg D, Hoepken HH, Gasser T, Krüger R, Winklhofer KF, Vogel F, Reichert AS, Auburger G, Kahle PJ, Schmid B, Haass C (2007) Loss-of-function of human PINK1 results in mitochondrial pathology and can be rescued by parkin. J Neurosci 27:12413-12418. CrossRef Medline

Fang Y, Bonini NM (2012) Axon degeneration and regeneration: insights from Drosophila models of nerve injury. Annu Rev Cell Dev Biol 28:575597. CrossRef Medline

Fiala A (2007) Olfaction and olfactory learning in Drosophila: recent progress. Curr Opin Neurobiol 17:720-726. CrossRef Medline

Fischer JA, Giniger E, Maniatis T, Ptashne M (1988) GAL4 activates transcription in Drosophila. Nature 332:853-856. CrossRef Medline

Frank CA (2013) Homeostatic plasticity at the Drosophila neuromuscular junction. Neuropharmacology. Advance online publication. Retrieved June 24, 2013. doi: S0028-3908(13)00283-9. CrossRef Medline

Frank CA, Kennedy MJ, Goold CP, Marek KW, Davis GW (2006) Mechanisms underlying the rapid induction and sustained expression of synaptic homeostasis. Neuron 52:663-677. CrossRef Medline

Frank CA, Pielage J, Davis GW (2009) A presynaptic homeostatic signaling system composed of the Eph receptor, ephexin, Cdc42, and CaV2.1 calcium channels. Neuron 61:556-569. CrossRef Medline

Fuentes-Medel Y, Ashley J, Barria R, Maloney R, Freeman M, Budnik V (2012) Integration of a retrograde signal during synapse formation by glia-secreted TGF-beta ligand. Curr Biol 22:1831-1838. CrossRef Medline

Füger P, Behrends LB, Mertel S, Sigrist SJ, Rasse TM (2007) Live imaging of synapse development and measuring protein dynamics using two-color fluorescence recovery after photo-bleaching at Drosophila synapses. Nat Protoc 2:3285-3298. CrossRef Medline

Gautier CA, Kitada T, Shen J (2008) Loss of PINK1 causes mitochondrial functional defects and increased sensitivity to oxidative stress. Proc Natl Acad Sci U S A 105:11364-11369. CrossRef Medline

Geisler S, Holmström KM, Skujat D, Fiesel FC, Rothfuss OC, Kahle PJ, Springer W (2010) PINK1/Parkin-mediated mitophagy is dependent on VDAC1 and p62/SQSTM1. Nat Cell Biol 12:119-131. CrossRef Medline

Ghannad-Rezaie M, Wang X, Mishra B, Collins C, Chronis N (2012) Microfluidic chips for in vivo imaging of cellular responses to neural injury in Drosophila larvae. PloS One 7:e29869. CrossRef Medline

Ghiani CA, Dell'Angelica EC (2011) Dysbindin-containing complexes and their proposed functions in brain: from zero to (too) many in a decade. ASN Neuro 3:2. CrossRef Medline

Glater EE, Megeath LJ, Stowers RS, Schwarz TL (2006) Axonal transport of mitochondria requires milton to recruit kinesin heavy chain and is light chain independent. J Cell Biol 173:545-557. CrossRef Medline

Golic KG (1991) Site-specific recombination between homologous chromosomes in Drosophila. Science 252:958-961. CrossRef Medline

Golic KG, Lindquist S (1989) The FLP recombinase of yeast catalyzes sitespecific recombination in the Drosophila genome. Cell 59:499-509. CrossRef Medline

Greenspan RJ (2008) Seymour Benzer (1921-2007). Curr Biol 18:R106R110. CrossRef Medline

Greig S, Akam M (1993) Homeotic genes autonomously specify one aspect of pattern in the Drosophila mesoderm. Nature 362:630-632. CrossRef Medline

Guo X, Macleod GT, Wellington A, Hu F, Panchumarthi S, Schoenfield M, Marin L, Charlton MP, Atwood HL, Zinsmaier KE (2005) The GTPase dMiro is required for axonal transport of mitochondria to Drosophila synapses. Neuron 47:379-393. CrossRef Medline

Haddad DM, Vilain S, Vos M, Esposito G, Matta S, Kalscheuer VM, Craessaerts K, Leyssen M, Nascimento RM, Vianna-Morgante AM, De 
Strooper B, Van Esch H, Morais VA, Verstreken P (2013) Mutations in the intellectual disability gene ube2a cause neuronal dysfunction and impair parkin-dependent mitophagy. Mol Cell 50:831-843. CrossRef Medline

Hamasaka Y, Wegener C, Nässel DR (2005) GABA modulates Drosophila circadian clock neurons via GABAB receptors and decreases in calcium. J Neurobiol 65:225-240. CrossRef Medline

Hamasaka Y, Rieger D, Parmentier ML, Grau Y, Helfrich-Förster C, Nässel DR (2007) Glutamate and its metabotropic receptor in Drosophila clock neuron circuits. J Comp Neurol 505:32-45. CrossRef Medline

Hammarlund M, Nix P, Hauth L, Jorgensen EM, Bastiani M (2009) Axon regeneration requires a conserved MAP kinase pathway. Science 323:802806. CrossRef Medline

Helfrich-Forster C (1998) Robust circadian rhythmicity of Drosophila melanogaster requires the presence of lateral neurons: a brain-behavioral study of disconnected mutants. J Comp Physiol A Neuroethol Sens Neural Behav Physiol 182:435-453. CrossRef Medline

Henne WM, Buchkovich NJ, Emr SD (2011) The ESCRT pathway. Dev Cell 21:77-91. CrossRef Medline

Hensch TK (2004) Critical period regulation. Annu Rev Neurosci 27:549579. CrossRef Medline

Hoopfer ED, McLaughlin T, Watts RJ, Schuldiner O, O'Leary DD, Luo L (2006) Wlds protection distinguishes axon degeneration following injury from naturally occurring developmental pruning. Neuron 50:883895. CrossRef Medline

Iijima-Ando K, Sekiya M, Maruko-Otake A, Ohtake Y, Suzuki E, Lu B, Iijima KM (2012) Loss of axonal mitochondria promotes tau-mediated neurodegeneration and Alzheimer's disease-related tau phosphorylation via PAR-1. PLoS Genet 8:e1002918. CrossRef Medline

Jan YN, Jan LY, Dennis MJ (1977) Two mutations of synaptic transmission in Drosophila. Proc R Soc Lond B Biol Sci 198:87-108. CrossRef Medline

Kaiser K (1993) Second generation enhancer traps. Curr Biol 3:560-562. CrossRef Medline

Khuong TM, Habets RL, Kuenen S, Witkowska A, Kasprowicz J, Swerts J, Jahn R, van den Bogaart G, Verstreken P (2013) Synaptic PI(3,4,5)P3 is required for Syntaxin1A clustering and neurotransmitter release. Neuron 77:1097-1108. CrossRef Medline

Kim S, Wairkar YP, Daniels RW, DiAntonio A (2010) The novel endosomal membrane protein Ema interacts with the class C Vps-HOPS complex to promote endosomal maturation. J Cell Biol 188:717-734. CrossRef Medline

Kitada T, Asakawa S, Hattori N, Matsumine H, Yamamura Y, Minoshima S, Yokochi M, Mizuno Y, Shimizu N (1998) Mutations in the parkin gene cause autosomal recessive juvenile parkinsonism. Nature 392:605-608. CrossRef Medline

Klinedinst S, Wang X, Xiong X, Haenfler JM, Collins CA (2013) Independent pathways downstream of the Wnd/DLK MAPKKK regulate synaptic structure, axonal transport, and injury signaling. J Neurosci 33:1276412778. CrossRef Medline

Koles K, Nunnari J, Korkut C, Barria R, Brewer C, Li Y, Leszyk J, Zhang B, Budnik V (2012) Mechanism of evenness interrupted (Evi)-exosome release at synaptic boutons. J Biol Chem 287:16820-16834. CrossRef Medline

Konopka RJ, Benzer S (1971) Clock mutants of Drosophila melanogaster. Proc Natl Acad Sci U S A 68:2112-2116. CrossRef Medline

Korkut C, Ataman B, Ramachandran P, Ashley J, Barria R, Gherbesi N, Budnik V (2009) Trans-synaptic transmission of vesicular Wnt signals through Evi/Wntless. Cell 139:393-404. CrossRef Medline

Lauwers E, Verstreken P (2013) Chaperoning the synapse-NMNAT protects Bruchpilot from crashing. EMBO Rep 14:5-6. CrossRef Medline

Lee S, Liu HP, Lin WY, Guo H, Lu B (2010) LRRK2 kinase regulates synaptic morphology through distinct substrates at the presynaptic and postsynaptic compartments of the Drosophila neuromuscular junction. J Neurosci 30:16959-16969. CrossRef Medline

Lee T, Luo L (2001) Mosaic analysis with a repressible cell marker (MARCM) for Drosophila neural development. Trends Neurosci 24:251254. CrossRef Medline

Leyssen M, Ayaz D, Hébert SS, Reeve S, De Strooper B, Hassan BA (2005) Amyloid precursor protein promotes post-developmental neurite arborization in the Drosophila brain. EMBO J 24:2944-2955. CrossRef Medline

Littleton JT (2000) A genomic analysis of membrane trafficking and neu- rotransmitter release in Drosophila. J Cell Biol 150:F77-F82. CrossRef Medline

Littleton JT, Ganetzky B (2000) Ion channels and synaptic organization: analysis of the Drosophila genome. Neuron 26:35-43. CrossRef Medline

Liu KS, Siebert M, Mertel S, Knoche E, Wegener S, Wichmann C, Matkovic T, Muhammad K, Depner H, Mettke C, Bückers J, Hell SW, Müller M, Davis GW, Schmitz D, Sigrist SJ (2011) RIM-binding protein, a central part of the active zone, is essential for neurotransmitter release. Science 334: 1565-1569. CrossRef Medline

Liu S, Sawada T, Lee S, Yu W, Silverio G, Alapatt P, Millan I, Shen A, Saxton W, Kanao T, Takahashi R, Hattori N, Imai Y, Lu B (2012) Parkinson's disease-associated kinase PINK1 regulates Miro protein level and axonal transport of mitochondria. PLoS Genet 8:e1002537. CrossRef Medline

Lloyd TE, Verstreken P, Ostrin EJ, Phillippi A, Lichtarge O, Bellen HJ (2000) A genome-wide search for synaptic vesicle cycle proteins in Drosophila. Neuron 26:45-50. CrossRef Medline

MacDonald JM, Beach MG, Porpiglia E, Sheehan AE, Watts RJ, Freeman MR (2006) The Drosophila cell corpse engulfment receptor Draper mediates glial clearance of severed axons. Neuron 50:869-881. CrossRef Medline

Malpel S, Klarsfeld A, Rouyer F (2002) Larval optic nerve and adult extraretinal photoreceptors sequentially associate with clock neurons during Drosophila brain development. Development 129:1443-1453. Medline

Marqués G, Zhang B (2006) Retrograde signaling that regulates synaptic development and function at the Drosophila neuromuscular junction. Int Rev Neurobiol 75:267-285. CrossRef Medline

Marqués G, Bao H, Haerry TE, Shimell MJ, Duchek P, Zhang B, O’Connor MB (2002) The Drosophila BMP type II receptor Wishful Thinking regulates neuromuscular synapse morphology and function. Neuron 33: 529-543. CrossRef Medline

Massaro CM, Pielage J, Davis GW (2009) Molecular mechanisms that enhance synapse stability despite persistent disruption of the spectrin/ ankyrin/microtubule cytoskeleton. J Cell Biol 187:101-117. CrossRef Medline

Matta S, Van Kolen K, da Cunha R, van den Bogaart G, Mandemakers W, Miśkiewicz K, De Bock PJ, Morais VA, Vilain S, Haddad D, Delbroek L, Swerts J, Chávez-Gutiérrez L, Esposito G, Daneels G, Karran E, Holt M, Gevaert K, Moechars DW, De Strooper B, et al. (2012) LRRK2 controls an EndoA phosphorylation cycle in synaptic endocytosis. Neuron 75: 1008-1021. CrossRef Medline

Mazzoni EO, Desplan C, Blau J (2005) Circadian pacemaker neurons transmit and modulate visual information to control a rapid behavioral response. Neuron 45:293-300. CrossRef Medline

Milosevic I, Giovedi S, Lou X, Raimondi A, Collesi C, Shen H, Paradise S, O’Toole E, Ferguson S, Cremona O, De Camilli P (2011) Recruitment of endophilin to clathrin-coated pit necks is required for efficient vesicle uncoating after fission. Neuron 72:587-601. CrossRef Medline

Miśkiewicz K, Jose LE, Bento-Abreu A, Fislage M, Taes I, Kasprowicz J, Swerts J, Sigrist S, Versées W, Robberecht W, Verstreken P (2011) ELP3 controls active zone morphology by acetylating the ELKS family member Bruchpilot. Neuron 72:776-788. CrossRef Medline

Morais VA, Verstreken P, Roethig A, Smet J, Snellinx A, Vanbrabant M, Haddad D, Frezza C, Mandemakers W, Vogt-Weisenhorn D, Van Coster R, Wurst W, Scorrano L, De Strooper B (2009) Parkinson's disease mutations in PINK1 result in decreased Complex I activity and deficient synaptic function. EMBO Mol Med 1:99-111. CrossRef Medline

Muhammad A, Flores I, Zhang H, Yu R, Staniszewski A, Planel E, Herman M, Ho L, Kreber R, Honig LS, Ganetzky B, Duff K, Arancio O, Small SA (2008) Retromer deficiency observed in Alzheimer's disease causes hippocampal dysfunction, neurodegeneration, and Abeta accumulation. Proc Natl Acad Sci U S A 105:7327-7332. CrossRef Medline

Müller M, Davis GW (2012) Transsynaptic control of presynaptic Ca(2) $(+)$ influx achieves homeostatic potentiation of neurotransmitter release. Curr Biol 22:1102-1108. CrossRef Medline

Müller M, Pym EC, Tong A, Davis GW (2011) Rab3-GAP controls the progression of synaptic homeostasis at a late stage of vesicle release. Neuron 69:749-762. CrossRef Medline

Müller M, Liu KS, Sigrist SJ, Davis GW (2012) RIM controls homeostatic plasticity through modulation of the readily-releasable vesicle pool. J Neurosci 32:16574-16585. CrossRef Medline

Munck S, Miśkiewicz K, Sannerud R, Menchon SA, Jose L, Heintzmann R, Verstreken P, Annaert W (2012) Sub-diffraction imaging on standard 
microscopes through photobleaching microscopy with non-linear processing. J Cell Sci 125:2257-2266. CrossRef Medline

Narendra D, Tanaka A, Suen DF, Youle RJ (2008) Parkin is recruited selectively to impaired mitochondria and promotes their autophagy. J Cell Biol 183:795-803. CrossRef Medline

Narendra D, Walker JE, Youle R (2012) Mitochondrial quality control mediated by PINK1 and Parkin: links to parkinsonism. Cold Spring Harbor Perspect Biol 4:11. CrossRef Medline

Nelson SB, Turrigiano GG (2008) Strength through diversity. Neuron 60: 477-482. CrossRef Medline

Ni JQ, Markstein M, Binari R, Pfeiffer B, Liu LP, Villalta C, Booker M, Perkins L, Perrimon N (2008) Vector and parameters for targeted transgenic RNA interference in Drosophila melanogaster. Nat Methods 5:49-51. Medline

Ni JQ, Liu LP, Binari R, Hardy R, Shim HS, Cavallaro A, Booker M, Pfeiffer BD, Markstein M, Wang H, Villalta C, Laverty TR, Perkins LA, Perrimon N (2009) A Drosophila resource of transgenic RNAi lines for neurogenetics. Genetics 182:1089-1100. CrossRef Medline

O'Connor-Giles KM, Ho LL, Ganetzky B (2008) Nervous wreck interacts with thickveins and the endocytic machinery to attenuate retrograde BMP signaling during synaptic growth. Neuron 58:507-518. CrossRef Medline

Opazo F, Punge A, Bückers J, Hoopmann P, Kastrup L, Hell SW, Rizzoli SO (2010) Limited intermixing of synaptic vesicle components upon vesicle recycling. Traffic 11:800-812. CrossRef Medline

Osterloh JM, Yang J, Rooney TM, Fox AN, Adalbert R, Powell EH, Sheehan AE, Avery MA, Hackett R, Logan MA, MacDonald JM, Ziegenfuss JS, Milde S, Hou YJ, Nathan C, Ding A, Brown RH Jr, Conforti L, Coleman $\mathrm{M}$, Tessier-Lavigne M, et al. (2012) dSarm/Sarm1 is required for activation of an injury-induced axon death pathway. Science 337:481-484. CrossRef Medline

Owald D, Fouquet W, Schmidt M, Wichmann C, Mertel S, Depner H, Christiansen F, Zube C, Quentin C, Körner J, Urlaub H, Mechtler K, Sigrist SJ (2010) A Syd-1 homologue regulates pre- and postsynaptic maturation in Drosophila. J Cell Biol 188:565-579. CrossRef Medline

Owald D, Khorramshahi O, Gupta VK, Banovic D, Depner H, Fouquet W, Wichmann C, Mertel S, Eimer S, Reynolds E, Holt M, Aberle H, Sigrist SJ (2012) Cooperation of Syd-1 with Neurexin synchronizes pre- with postsynaptic assembly. Nat Neurosci 15:1219-1226. CrossRef Medline

Packard M, Koo ES, Gorczyca M, Sharpe J, Cumberledge S, Budnik V (2002) The Drosophila Wnt, wingless, provides an essential signal for pre- and postsynaptic differentiation. Cell 111:319-330. CrossRef Medline

Paradis S, Sweeney ST, Davis GW (2001) Homeostatic control of presynaptic release is triggered by postsynaptic membrane depolarization. Neuron 30:737-749. CrossRef Medline

Park J, Lee SB, Lee S, Kim Y, Song S, Kim S, Bae E, Kim J, Shong M, Kim JM, Chung J (2006) Mitochondrial dysfunction in Drosophila PINK1 mutants is complemented by parkin. Nature 441:1157-1161. CrossRef Medline

Penney J, Tsurudome K, Liao EH, Elazzouzi F, Livingstone M, Gonzalez M, Sonenberg N, Haghighi AP (2012) TOR is required for the retrograde regulation of synaptic homeostasis at the Drosophila neuromuscular junction. Neuron 74:166-178. CrossRef Medline

Petersen SA, Fetter RD, Noordermeer JN, Goodman CS, DiAntonio A (1997) Genetic analysis of glutamate receptors in Drosophila reveals a retrograde signal regulating presynaptic transmitter release. Neuron 19: 1237-1248. CrossRef Medline

Piccoli G, Condliffe SB, Bauer M, Giesert F, Boldt K, De Astis S, Meixner A, Sarioglu H, Vogt-Weisenhorn DM, Wurst W, Gloeckner CJ, Matteoli M, Sala C, Ueffing M (2011) LRRK2 controls synaptic vesicle storage and mobilization within the recycling pool. J Neurosci 31:2225-2237. CrossRef Medline

Poduri A, Lowenstein D (2011) Epilepsy genetics: past, present, and future. Curr Opin Genet Dev 21:325-332. CrossRef Medline

Poole AC, Thomas RE, Andrews LA, McBride HM, Whitworth AJ, Pallanck LJ (2008) The PINK1/Parkin pathway regulates mitochondrial morphology. Proc Natl Acad Sci U S A 105:1638-1643. CrossRef Medline

Pozo K, Goda Y (2010) Unraveling mechanisms of homeostatic synaptic plasticity. Neuron 66:337-351. CrossRef Medline

Rodal AA, Motola-Barnes RN, Littleton JT (2008) Nervous wreck and Cdc42 cooperate to regulate endocytic actin assembly during synaptic growth. J Neurosci 28:8316-8325. CrossRef Medline

Rodal AA, Blunk AD, Akbergenova Y, Jorquera RA, Buhl LK, Littleton JT
(2011) A presynaptic endosomal trafficking pathway controls synaptic growth signaling. J Cell Biol 193:201-217. CrossRef Medline

Rong YS, Golic KG (2000) Gene targeting by homologous recombination in Drosophila. Science 288:2013-2018. CrossRef Medline

Ross CA, Margolis RL, Reading SA, Pletnikov M, Coyle JT (2006) Neurobiology of schizophrenia. Neuron 52:139-153. CrossRef Medline

Rubin GM, Spradling AC (1982) Genetic transformation of Drosophila with transposable element vectors. Science 218:348-353. CrossRef Medline

Schmid A, Hallermann S, Kittel RJ, Khorramshahi O, Frölich AM, Quentin C, Rasse TM, Mertel S, Heckmann M, Sigrist SJ (2008) Activity-dependent site-specific changes of glutamate receptor composition in vivo. Nat neurosci 11:659-666. CrossRef Medline

Schmucker D, Taubert H, Jäckle H (1992) Formation of the Drosophila larval photoreceptor organ and its neuronal differentiation require continuous Kruppel gene activity. Neuron 9:1025-1039. CrossRef Medline

Schwarz TL (2006) Transmitter release at the neuromuscular junction. Int Rev Neurobiol 75:105-144. CrossRef Medline

Shidara Y, Hollenbeck PJ (2010) Defects in mitochondrial axonal transport and membrane potential without increased reactive oxygen species production in a Drosophila model of Friedreich ataxia. J Neurosci 30:11369 11378. CrossRef Medline

Shin JE, Cho Y, Beirowski B, Milbrandt J, Cavalli V, DiAntonio A (2012) Dual leucine zipper kinase is required for retrograde injury signaling and axonal regeneration. Neuron 74:1015-1022. CrossRef Medline

Small SA (2008) Retromer sorting: a pathogenic pathway in late-onset Alzheimer disease. Arch Neurol 65:323-328. CrossRef Medline

Song Y, Ori-McKenney KM, Zheng Y, Han C, Jan LY, Jan YN (2012) Regeneration of Drosophila sensory neuron axons and dendrites is regulated by the Akt pathway involving Pten and microRNA bantam. Genes Dev 26:1612-1625. CrossRef Medline

Stone MC, Nguyen MM, Tao J, Allender DL, Rolls MM (2010) Global upregulation of microtubule dynamics and polarity reversal during regeneration of an axon from a dendrite. Mol Biol Cell 21:767-777. CrossRef Medline

Stowers RS, Megeath LJ, Górska-Andrzejak J, Meinertzhagen IA, Schwarz TL (2002) Axonal transport of mitochondria to synapses depends on milton, a novel Drosophila protein. Neuron 36:1063-1077. CrossRef Medline

Tao J, Rolls MM (2011) Dendrites have a rapid program of injury-induced degeneration that is molecularly distinct from developmental pruning. J Neurosci 31:5398-5405. CrossRef Medline

Thomas BJ, Wassarman DA (1999) A fly's eye view of biology. Trends Genet 15:184-190. CrossRef Medline

Trempe JF, Chen CX, Grenier K, Camacho EM, Kozlov G, McPherson PS, Gehring K, Fon EA (2009) SH3 domains from a subset of BAR proteins define a Ubl-binding domain and implicate parkin in synaptic ubiquitination. Mol Cell 36:1034-1047. CrossRef Medline

Tsurudome K, Tsang K, Liao EH, Ball R, Penney J, Yang JS, Elazzouzi F, He T, Chishti A, Lnenicka G, Lai EC, Haghighi AP (2010) The Drosophila miR-310 cluster negatively regulates synaptic strength at the neuromuscular junction. Neuron 68:879-893. CrossRef Medline

Turrigiano GG (2008) The self-tuning neuron: synaptic scaling of excitatory synapses. Cell 135:422-435. CrossRef Medline

Turrigiano GG, Leslie KR, Desai NS, Rutherford LC, Nelson SB (1998) Activity-dependent scaling of quantal amplitude in neocortical neurons. Nature 391:892-896. CrossRef Medline

Uytterhoeven V, Kuenen S, Kasprowicz J, Miśkiewicz K, Verstreken P (2011) Loss of skywalker reveals synaptic endosomes as sorting stations for synaptic vesicle proteins. Cell 145:117-132. CrossRef Medline

Valente EM, Abou-Sleiman PM, Caputo V, Muqit MM, Harvey K, Gispert S, Ali Z, Del Turco D, Bentivoglio AR, Healy DG, Albanese A, Nussbaum R, González-Maldonado R, Deller T, Salvi S, Cortelli P, Gilks WP, Latchman DS, Harvey RJ, Dallapiccola B, et al. (2004) Hereditary early-onset Parkinson's disease caused by mutations in PINK1. Science 304:1158-1160. CrossRef Medline

Venken KJ, Simpson JH, Bellen HJ (2011) Genetic manipulation of genes and cells in the nervous system of the fruit fly. Neuron 72:202-230. CrossRef Medline

Verstreken P, Kjaerulff O, Lloyd TE, Atkinson R, Zhou Y, Meinertzhagen IA, Bellen HJ (2002) Endophilin mutations block clathrin-mediated endo- 
cytosis but not neurotransmitter release. Cell 109:101-112. CrossRef Medline

Verstreken P, Ly CV, Venken KJ, Koh TW, Zhou Y, Bellen HJ (2005) Synaptic mitochondria are critical for mobilization of reserve pool vesicles at Drosophila neuromuscular junctions. Neuron 47:365-378. CrossRef Medline

Vilain S, Esposito G, Haddad D, Schaap O, Dobreva MP, Vos M, Van Meensel S, Morais VA, De Strooper B, Verstreken P (2012) The yeast complex I equivalent NADH dehydrogenase rescues pink1 mutants. PLoS Genet 8:e1002456. CrossRef Medline

Vincow ES, Merrihew G, Thomas RE, Shulman NJ, Beyer RP, MacCoss MJ, Pallanck LJ (2013) The PINK1-Parkin pathway promotes both mitophagy and selective respiratory chain turnover in vivo. Proc Natl Acad Sci U S A 110:6400-6405. CrossRef Medline

Vitureira N, Letellier M, Goda Y (2012) Homeostatic synaptic plasticity: from single synapses to neural circuits. Curr Opin Neurobiol 22:516-521. CrossRef Medline

Vos M, Esposito G, Edirisinghe JN, Vilain S, Haddad DM, Slabbaert JR, Van Meensel S, Schaap O, De Strooper B, Meganathan R, Morais VA, Verstreken P (2012) Vitamin K2 is a mitochondrial electron carrier that rescues pink1 deficiency. Science 336:1306-1310. CrossRef Medline

Wan HI, DiAntonio A, Fetter RD, Bergstrom K, Strauss R, Goodman CS (2000) Highwire regulates synaptic growth in Drosophila. Neuron 26: 313-329. CrossRef Medline

Wang JT, Medress ZA, Barres BA (2012) Axon degeneration: molecular mechanisms of a self-destruction pathway. J Cell Biol 196:7-18. CrossRef Medline

Wang X, Shaw WR, Tsang HT, Reid E, O'Kane CJ (2007) Drosophila spichthyin inhibits BMP signaling and regulates synaptic growth and axonal microtubules. Nat Neurosci 10:177-185. CrossRef Medline

Wang X, Winter D, Ashrafi G, Schlehe J, Wong YL, Selkoe D, Rice S, Steen J, LaVoie MJ, Schwarz TL (2011) PINK1 and Parkin target Miro for phosphorylation and degradation to arrest mitochondrial motility. Cell 147: 893-906. CrossRef Medline

Wen L, Tang FL, Hong Y, Luo SW, Wang CL, He W, Shen C, Jung JU, Xiong F, Lee DH, Zhang QG, Brann D, Kim TW, Yan R, Mei L, Xiong WC (2011) VPS35 haploinsufficiency increases Alzheimer's disease neuropathology. J Cell Biol 195:765-779. CrossRef Medline
Wilson C, Pearson RK, Bellen HJ, O'Kane CJ, Grossniklaus U, Gehring WJ (1989) P-element-mediated enhancer detection: an efficient method for isolating and characterizing developmentally regulated genes in Drosophila. Genes Dev 3:1301-1313. CrossRef Medline

Wu CF, Ganetzky B (1980) Genetic alteration of nerve membrane excitability in temperature-sensitive paralytic mutants of Drosophila melanogaster. Nature 286:814-816. CrossRef Medline

Wu CF, Ganetzky B, Haugland FN, Liu AX (1983) Potassium currents in Drosophila: different components affected by mutations of two genes. Science 220:1076-1078. CrossRef Medline

Wucherpfennig T, Wilsch-Bräuninger M, González-Gaitán M (2003) Role of Drosophila Rab5 during endosomal trafficking at the synapse and evoked neurotransmitter release. J Cell Biol 161:609-624. CrossRef Medline

Xiong X, Collins CA (2012) A conditioning lesion protects axons from degeneration via the Wallenda/DLK MAP kinase signaling cascade. J Neurosci 32:610-615. CrossRef Medline

Xiong X, Wang X, Ewanek R, Bhat P, Diantonio A, Collins CA (2010) Protein turnover of the Wallenda/DLK kinase regulates a retrograde response to axonal injury. J Cell Biol 191:211-223. CrossRef Medline

Xiong X, Hao Y, Sun K, Li J, Li X, Mishra B, Soppina P, Wu C, Hume RI, Collins CA (2012) The Highwire ubiquitin ligase promotes axonal degeneration by tuning levels of Nmnat protein. PLoS Biol 10:e1001440. CrossRef Medline

Yan D, Wu Z, Chisholm AD, Jin Y (2009) The DLK-1 kinase promotes mRNA stability and local translation in C. elegans synapses and axon regeneration. Cell 138:1005-1018. CrossRef Medline

Yang Y, Gehrke S, Imai Y, Huang Z, Ouyang Y, Wang JW, Yang L, Beal MF, Vogel H, Lu B (2006) Mitochondrial pathology and muscle and dopaminergic neuron degeneration caused by inactivation of Drosophila Pink1 is rescued by Parkin. Proc Natl Acad Sci U S A 103:10793-10798. CrossRef Medline

Yuan Q, Xiang Y, Yan Z, Han C, Jan LY, Jan YN (2011) Light-induced structural and functional plasticity in Drosophila larval visual system. Science 333:1458-1462. CrossRef Medline

Zenisek D, Steyer JA, Almers W (2000) Transport, capture and exocytosis of single synaptic vesicles at active zones. Nature 406:849-854. CrossRef Medline 